\title{
Cloning and Sequence Analysis of Lipase Gene of Halophilic Bacteria Isolated from Mud Crater of Bledug Kuwu, Central Java, Indonesia
}

\author{
Mukhammad Asyari' ${ }^{1}$ Pingkan Aditiawati ${ }^{2}$, \\ Akhmaloka ${ }^{1}$ and Rukman Hertadi ${ }^{1 *}$ \\ ${ }^{1}$ Biochemistry Research Group, Faculty of Mathematics and Natural Sciences, \\ Institut Teknologi Bandung, Jl. Ganesha no. 10 Bandung 40132, Indonesia. \\ ${ }^{2}$ Microbial Biotechnology Research Group, School of Life Sciences and Technology, \\ Institut Teknologi Bandung, Jl. Ganesha no. 10 Bandung 40132, Indonesia.
}

DOI: http://dx.doi.org/10.13005/bbra/1856

(Received: 03 August 2015; accepted: 19 September 2015)

\begin{abstract}
Five lipase genes (lipab4, lipab8, lipab15, lipag18, and lipab18) have been isolated from Halomonas and Chromohalobacter local strains of Bledug Kuwu isolates. Based on amino acid sequence analysis, the genes showed some unique motif of amino acid sequences. All of lipases were classified as a member of family IV (HSL=hormonesensitive lipase). These lipases show high similarities of conserved regions with lipolytic of Halomonas and formed a distinct cluster with other types of HSL, such as esterase/ lipase and carboxylesterase. All of lipases contain more negative charged of amino acid residues compared to the mesophilic and thermophilic ones, and tend to have similarity to lipases of moderate halophilics. The result of homology and phylogenetic analysis showed that these lipases were clustered into three groups. Group I (lipab8, lipab18 and lipag18) closed to lipolytic gene of Halomonas elongata DSM 2581, while groups II (lipab4) and III (lipab15) created new branches in the phylogenetic tree. In addition, analysis of GC, GC-AT and GC-AT content on the codon usage of the genes revealed the unique profile compared to that the other lipase genes.
\end{abstract}

Key words: Halomonas, Chromohalobacter, Halostable lipase, HSL Family, GC-AT content, Bledug Kuwu.

A lipase is an enzyme that catalyzes hydrolysis of triacylglycerol into fatty acids and glycerol at water-lipid interface, and also an esterification reaction in non-aqueous environment, i.e. organic solvents ${ }^{1,2}$. In some industrial process, the reactions may be inhibited by high concentrations of salt, organic solvents and high temperatures. Therefore, lipases that have optimum activity within wide range of temperatures, salinity, pHs, and various organic solvents, are demanded by most industries ${ }^{3,4}$. One

\footnotetext{
* To whom all correspondence should be addressed. Tel.: +62-22-2502103; Fax: +62-22-2504154; E-mail: rukman@chem.itb.ac.id
}

of the potential sources of lipases is extremophilic microorganisms, such as thermophiles for thermostable lipase ${ }^{5-10}$ and halophiles for halostable lipase $\mathrm{e}^{11-13}$.

Halophiles are defined as microorganisms that live in hypersaline environments ${ }^{14,15}$. There are numerous reports about extracellular lipase production from halophiles i.e. Salinivibrio sp. strain SA-2, Natronococcus sp., Salicola, Halovibrio, Halomonas, Oceanobacillus, Thalassobacillus, Halobacillus, Virgibacillus, Gracilibacillus, Salinicoccus, and Piscibacillus ${ }^{16-19}$. Li and Yu (2012) have isolated lipase from Chromohalobacter sp. LY7-8 that highly active towards p-nitrophenyl esters (C8 to C18) ${ }^{20}$. The 
purified lipase has molecular weight of $44 \mathrm{kDa}$ and exhibited optimum activity at $60^{\circ} \mathrm{C}, \mathrm{pH} 9.0$ and $12.5 \% \mathrm{NaCl}$. Significant inhibition of the lipase activity exhibited upon the addition of EDTA, PMSF and DEPC, indicating it is a metalloenzyme with serine and histidine residues essential for its catalytic function. Perez et al., (2011) have cloned, overexpressed and purified, a lipolytic enzyme from the moderate halophilic Marinobacter lipolyticus SM19 into E.coli ${ }^{21}$. The enzyme showed unusual halophilic properties, since its optimum activity was observed in the absence of $\mathrm{NaCl}$ and inhibited by the presence of this salt. However, this enzyme exhibited remarkable stability in a wide variety of organic solvents including DMSO, DMF, methanol, ethanol, toluene, diethyl ether, propanol, and acetone. It has been reported that some halophilic bacteria can also live in organic solvent rich environment indicating their enzymes are also adaptive to such conditions ${ }^{22-24}$. Isolating lipase from halophilic bacteria, therefore will give higher probability to obtain the enzyme that stable and active in both extreme conditions, which are hypersaline and organic solvents.

Seven halophilic bacteria comprised of four Halomonas, one Chromohalobacter and two Pseudomonas strains have been isolated and identified as potential sources for halostable lipases. Four Halomonas and one Chromohalobacter strains showed high halotolerant levels and classified as moderate halophilics, meanwhile the Pseudomonas were classified as low halotolerant level ${ }^{25}$. One of the Pseudomonas was shown as the potential source of organic solvent stable lipase ${ }^{26}$. Therefore, there is possibility that the other lipase isolated from the same environment is also stable in organic solvents. For further probe the characterized of the lipases, here we present cloning and sequence analysis of the genes.

\section{MATERIALSAND METHODS}

\section{Chemicals}

Common chemicals with pro analysis grade were purchased from Merck (Germany) and Sigma-Aldrich (USA). Bacterial growth nutrients, such as tryptone, yeast extract were obtained from Bio Basic (Canada). Biochemical reagents such as dNTPs, PCR Buffer, Taq DNA Polymerase were purchased from Fermentas (USA) and Kapa Biosystems (USA). Oligonucleotides (primers) were ordered from Macrogen (South Korea) and Integrated DNA Technologies (Singapore). Purification of PCR product used GeneJET Gel Extraction Kit (Thermo Scientific). The cloning was performed by using $p G E M-T$ easy vector and T4 DNA ligase purchased from Promega (USA). Restriction enzymes were purchased from Thermo Scientific (USA).

\section{Bacteria}

Five isolates of halophilic bacteria were obtained from our culture collections in the Laboratory of Biochemistry, Faculty of Mathematics and Natural Sciences, Institut Teknologi Bandung. The isolates were Halomonas meridiana BK-AB4 (AB4), Halomonas elongata BK-AB8 (AB8), Halomonas eurihalina BK-AB15 (AB15), Halomonas elongata BK-AG18 (AG18) and Chromohalobacter japonicus BK-AB18 $(\mathrm{AB} 18)^{25}$. Escherichia coli TOP 10 was used as host for gene cloning.

\section{Cultivation}

Five isolates were cultivated using modified media of Luria Berthani composed of $0.1 \%$ tryptone, $0.05 \%$ yeast extract and $10 \% \mathrm{NaCl}^{27}$. The cultures were incubated in shaker incubator at room temperature with aeration rate of $150 \mathrm{rpm}$.

\section{Isolation of Chromosomal DNA}

Isolation of chromosomal DNA was carried out using modified method of Zhou ${ }^{28}$. The collected DNA pellet was separated from the supernatant and dried with concentrator, subsequently followed by resuspension with 25-

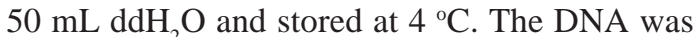
used for PCR.

\section{Cloning of Lipase Genes}

Cloning of lipase gene in each bacterial isolates was started by in vitro amplification of the gene by PCR technique ${ }^{29}$ using a pair of specific primers i.e. xFLipH3A (5'ATGCAGATCGATGCCTTTCGTCGC-3') and xRLipH3A(5'-TCATTCCACTCGTCGACCCAGC3'). A typical PCR mixture (50 $\mu \mathrm{L}$ in volume) was prepared by mixing $5 \mu \mathrm{L}$ of PCR buffer 10', $2.5 \mathrm{mM}$ $\mathrm{MgCl}_{2}, 250 \mu \mathrm{M}$ of deoxynucleosid-e triphosphate, $0.25 \mu \mathrm{M}$ of each primers, and 1.25 U of Taq DNA polymerase. PCR was conducted by the following protocol: an initial denaturation was set at $94{ }^{\circ} \mathrm{C}$ for 4 min followed by 35 cycles of denaturation 
(@30 s at $94^{\circ} \mathrm{C}$ ), an annealing was programmed at $59{ }^{\circ} \mathrm{C}$ for $30 \mathrm{~s}$, while an extension and final extension were carried out at the same temperature at $72{ }^{\circ} \mathrm{C}$ for $1 \mathrm{~min}$ and $5 \mathrm{~min}$, respectively ${ }^{29}$. The product of PCR was verified by electrophoresis technique using submerged horizontal electrophoresis cell for 50 min at 70 volts. The purification of PCR product was carried out by GeneJET Gel Extraction Kit. Finally, purified DNA was re-suspended to 50 $\mu \mathrm{L}$ buffers (10 mM Tris-HCl, $\mathrm{pH}$ 8.5). The purified DNA solution was stored at $-20{ }^{\circ} \mathrm{C}$.

Construction of recombinant plasmid was carried out by ligating the PCR products with $p G E M-T$ easy plasmid. The competent cell of $E$. coli Top 10 was prepared following the method described by Cohen $^{30}$. Transformation of E. coli was conducted by heat shock method ${ }^{31} .100 \mathrm{~mL}$ of the transformed cells were spreaded on LB agar (LBA) media containing $100 \mathrm{mg} / \mathrm{mL}$ of ampicillin, $15 \mathrm{mg} / \mathrm{mL}$ of tetracycline and incubated at $37^{\circ} \mathrm{C}$ for overnight. Plasmid isolation from the transformed cell was carried out by the alkaline lysis method ${ }^{32}$. Finally to verify the recombinant plasmid containing DNA insert, the plasmid was digested with EcoRI and visualized by agarose gel electrophoresis.

\section{Sequencing of Lipase Gene}

Lipase genes were sequenced by DideoxySanger dye terminator method ${ }^{33}$ at Macrogen, Seoul, Republic of Korea. The sequences were validated by analyzing the electrophoregram data using Sequence scanner 2 (Applied Biosystems). In order to combine the partial gene sequences into a full gene, we used DNA Baser Sequence Assembler v3 program (Heracle BioSoft).

Deduced Amino Acid Sequence Analysis of Lipase

Deduced amino acid sequences of five lipases were performed by in silico translation using Bioedit software and online server of ExPASy-Translate tool available at http:// web.expasy.org/translate/.

Homology analysis of five lipase sequences were carried out using NCBI-Blastp analysis program (http://blast.ncbi.nlm.nih.gov/ Blast.cgi). A hundred of high homologous sequences were used to generate phylogenetic profile using MEGA 6 software based on the Neighbor-Joining clustering method.

Amino acid composition and alignment analysis were performed using "Amino Acid Composition" and "ClustalW Multiple Alignment" programs which are integrated in the Bioedit software.

\section{Sequence Analysis of Lipase Gene}

The analysis of lipase gene sequences was carried out by evaluating contents of GC, GCAT, and GC-AT of codon usage. The last two analyses were conducted with Bioedit-software, while the third analysis was calculated with an online program available at http:// www.bioinformatics.org/sms2/ codon_usage.html. The analysis of "codon usage" was performed on the 1st, 2nd and 3rd base position. All analyzes above were not only performed on the five isolates lipase sequences but also to other lipase genes from the other microorganism.

\section{RESULTSAND DISCUSSION}

\section{Cloning and Sequencing of Lipase Genes}

Five lipase genes have been successfully amplified from Halomonas and Chromoholobacter local strains by PCR technique. The genes, namely lipab4, lipab8, lipab15, lipag18, and lipab18, have estimated length about $800 \mathrm{bp}$ (Figure 1). All of the genes were cloned into E. coli Top 10, sequenced and deposited to GenBank database (https://www.ncbi. nlm.nih.gov) with accession number of KJ676135.1, KJ676136.1, KJ676137.1, KJ676139.1, and KJ676138.1, respectively.

Homology and Phylogenetic Analysis of Lipases

Homology analysis of deduced amino acid sequences of five lipases were carried out using NCBI-Blastp program. The results showed that the five lipase sequences showed high similarities to several lipases, such as form Halomonas elongata DSM $2581^{34}$ with percent identity about $95-99 \%$, Gammaproteobacteria MFB021 ${ }^{35}$ with percent identity of $58-60 \%$ and Halomonas halodenitrificans ${ }^{36}$ with percent identity of $57 \%$. All lipases closed to Halomonas elongata DSM 2581 (Table 1).

Phylogenetic analysis generated a tree profile that five lipases distributed into three groups i.e. group I (lipab8, lipab18 and lipag18), groups II (lipab4) and III (lipab15). Group I closed to lipase of Halomonas elongata DSM 2581, meanwhile the group II and III formed new branches (Figure 2). Conserved Regions Analysis of The Lipases 100 best homologous sequences with the 
Table 1. The result of Blastp alignment for the five lipase genes

\begin{tabular}{lccc}
\hline Description & Total score & Ident & Accession \\
\hline Lipolytic protein [Halomonas elongata] & 538 & $100 \%$ & WP_013332507.1 \\
Lipase [Halomonas elongata] à lipab8 & 531 & $99 \%$ & AID66447.1 \\
Lipase [Chromohalobacter japonicus] àlipab18 & 528 & $98 \%$ & AID66449.1 \\
Lipase [Halomonas elongata] àlipag18 & 525 & $97 \%$ & AID66450.1 \\
Lipase [Halomonas meridiana] à lipab4 & 510 & $96 \%$ & AID66446.1 \\
Lipase [Halomonas eurihalina] à lipab15 & 509 & $95 \%$ & AID66448.1 \\
Lipolytic protein [Halomonas halodenitrificans] & 294 & $57 \%$ & WP_043487540.1 \\
Lipolytic protein [Gammaproteobacteria bacterium MFB021] & 293 & $58 \%$ & WP_035474917.1 \\
Lipolytic enzyme [Halomonas sp. HAL1] & 287 & $54 \%$ & WP_008960037.1 \\
Lipolytic enzyme [Halomonas sp. TD01] & 286 & $55 \%$ & WP_009721885.1 \\
Lipolytic protein [Halomonas zincidurans] & 286 & $53 \%$ & WP_031383322.1 \\
Hypothetical protein [Kushneria aurantia] & 285 & $57 \%$ & WP_019951967.1 \\
Lipolytic protein [Halomonas campaniensis] & 283 & $54 \%$ & WP_038485789.1 \\
Lipolytic protein [Halomonas sp. KO116] & 282 & $53 \%$ & WP_035566707.1 \\
Lipolytic protein [Halomonas sp. TG39a] & 281 & $53 \%$ & WP_035578065.1 \\
Lipolytic protein [Halomonas sp. HL-48] & 280 & $54 \%$ & WP_027335272.1 \\
MULTISPECIES: lipolytic protein [Halomonas] & 278 & $52 \%$ & WP_027959004.1 \\
Lipolytic protein [Halomonas alkaliantarctica] & 278 & $53 \%$ & WP_030072091.1 \\
Lipolytic protein [Halomonas titanicae] & 272 & $52 \%$ & WP_039859736.1 \\
Alpha/beta hydrolase fold-3 [Halomonas titanicae BH1] & 271 & $52 \%$ & ELY21010.1 \\
Lipolytic protein [Halomonas sp. S2151] & 270 & $52 \%$ & WP_045994799.1 \\
Hypothetical protein [Halomonas sp. PBN3] & 267 & $54 \%$ & WP_023005267.1 \\
Lipolytic enzyme [Halomonas sp. GFAJ-1] & 266 & $56 \%$ & WP_009099840.1 \\
Lipolytic protein [Halomonas sp. KHS3] & 261 & $53 \%$ & WP_041157980.1 \\
Lipolytic enzyme [Halomonas sp. A3H3] & 259 & $53 \%$ & WP_022524062.1 \\
Hypothetical protein [Halomonas smyrnensis] & 255 & $54 \%$ & WP_016855596.1 \\
\hline
\end{tabular}

Table 2. Amino acid differences between lipase of the five isolates with the Halomonas elongata

\begin{tabular}{|c|c|c|c|c|c|c|c|}
\hline Position & liphelo & lipab4 & lipab8 & lipab15 & lipab18 & lipag18 & Change of properties \\
\hline 34 & $\mathrm{~T} \rightarrow$ & A & A & $\mathrm{T}$ & A & $\mathrm{T}$ & $\mathrm{T}$ (uncharged) $\rightarrow \mathrm{A}$ (non polar) \\
\hline 98 & $\mathrm{C} \rightarrow$ & $\mathrm{C}$ & $\mathrm{C}$ & $\mathrm{R}$ & $\mathrm{C}$ & $\mathrm{R}$ & $\mathrm{C}$ (uncharged) $\rightarrow \mathrm{R}$ (positive) \\
\hline 101 & $\mathrm{I} \rightarrow$ & $\mathrm{I}$ & $\mathrm{I}$ & $\mathrm{L}$ & $\mathrm{I}$ & $\mathrm{I}$ & I (non polar) $\rightarrow$ L (non polar) \\
\hline 106 & $\mathrm{R} \rightarrow$ & $\mathrm{R}$ & $\mathrm{R}$ & $\mathrm{H}$ & $\mathrm{R}$ & $\mathrm{R}$ & $\mathrm{R}$ (positip) $\rightarrow \mathrm{H}$ (positip) \\
\hline 108 & $\mathrm{~L} \rightarrow$ & $\mathrm{L}$ & $\mathrm{L}$ & $\mathrm{L}$ & $\mathrm{L}$ & $\mathrm{I}$ & L (non polar) $\rightarrow$ I (non polar) \\
\hline 124 & $\mathrm{~T} \rightarrow$ & $\mathrm{T}$ & $\mathrm{T}$ & $\mathrm{A}$ & $\mathrm{T}$ & $\mathrm{T}$ & $\mathrm{T}$ (uncharged) $\rightarrow \mathrm{A}$ (non polar) \\
\hline 150 & $\mathrm{P} \rightarrow$ & $\mathrm{P}$ & $\mathrm{S}$ & $\mathrm{P}$ & $\mathrm{S}$ & $\mathrm{S}$ & $\mathrm{P}$ (non polar) $\rightarrow \mathrm{S}$ (uncharged) \\
\hline 154 & $\mathrm{~V} \rightarrow$ & $\mathrm{V}$ & $\mathrm{V}$ & $\mathrm{V}$ & $\mathrm{V}$ & $\mathrm{I}$ & $\mathrm{V}$ (non polar) $\rightarrow \mathrm{I}$ (non polar) \\
\hline 165 & $\mathrm{P} \rightarrow$ & $\mathrm{L}$ & $\mathrm{P}$ & $\mathrm{P}$ & $\mathrm{P}$ & $\mathrm{P}$ & $\mathrm{P}$ (non polar) $\rightarrow \mathrm{L}$ (non polar) \\
\hline 166 & $\mathrm{~T} \rightarrow$ & $\mathrm{P}$ & $\mathrm{T}$ & $\mathrm{T}$ & $\mathrm{T}$ & $\mathrm{T}$ & $\mathrm{T}$ (uncharged) $\rightarrow \mathrm{P}$ (non polar) \\
\hline 167 & $\mathrm{~L} \rightarrow$ & $\mathrm{P}$ & $\mathrm{L}$ & $\mathrm{P}$ & $\mathrm{L}$ & $\mathrm{L}$ & $\mathrm{L}($ uncharged) $\rightarrow \mathrm{P}$ (non polar) \\
\hline 168 & $\mathrm{Q} \rightarrow$ & $\mathrm{E}$ & $\mathrm{Q}$ & $\mathrm{E}$ & $\mathrm{Q}$ & $\mathrm{Q}$ & $\mathrm{Q}$ (uncharged) $\rightarrow \mathrm{E}$ (negative) \\
\hline 184 & $\mathrm{~T} \rightarrow$ & $\mathrm{T}$ & $\mathrm{T}$ & $\mathrm{S}$ & $\mathrm{T}$ & $\mathrm{T}$ & $\mathrm{T}$ (uncharged) $\rightarrow \mathrm{S}$ (uncharged) \\
\hline 188 & $\mathrm{~A} \rightarrow$ & $\mathrm{D}$ & A & $\mathrm{T}$ & A & A & $\mathrm{A}($ non polar) $\rightarrow \mathrm{T} ; \mathrm{D}$ (uc;neg) \\
\hline 189 & $\mathrm{I} \rightarrow$ & $\mathrm{I}$ & $\mathrm{I}$ & I & $\mathrm{I}$ & $\mathrm{F}$ & I (non polar) $\rightarrow$ F (non polar) \\
\hline 190 & $\mathrm{~V} \rightarrow$ & $\mathrm{V}$ & $\mathrm{V}$ & A & $\mathrm{V}$ & $\mathrm{V}$ & A (non polar) $\rightarrow \mathrm{V}$ (non polar) \\
\hline 191 & $\mathrm{D} \rightarrow$ & $\mathrm{D}$ & $\mathrm{D}$ & G & $\mathrm{D}$ & $\mathrm{D}$ & $\mathrm{D}$ (negative) $\rightarrow \mathrm{G}$ (non polar) \\
\hline 195 & $\mathrm{M} \rightarrow$ & $\mathrm{I}$ & M & M & M & M & M (uncharged) $\rightarrow$ I (non polar) \\
\hline 197 & $\mathrm{D} \rightarrow$ & $\mathrm{D}$ & $\mathrm{D}$ & G & $\mathrm{D}$ & $\mathrm{D}$ & $\mathrm{D}$ (negative) $\rightarrow \mathrm{G}$ (non polar) \\
\hline 199 & $\mathrm{D} \rightarrow$ & $\mathrm{A}$ & A & A & A & $\mathrm{D}$ & $\mathrm{D}$ (negative) $\rightarrow \mathrm{A}$ (non polar) \\
\hline 210 & $\mathrm{~T} \rightarrow$ & $\mathrm{T}$ & $\mathrm{T}$ & A & $\mathrm{T}$ & $\mathrm{T}$ & $\mathrm{T}$ (uncharged) $\rightarrow \mathrm{A}$ (non polar) \\
\hline 234 & $\mathrm{I} \rightarrow$ & $\mathrm{V}$ & $\mathrm{V}$ & $\mathrm{V}$ & $\mathrm{V}$ & $\mathrm{V}$ & $\mathrm{I}$ (non polar) $\rightarrow \mathrm{V}$ (non polar) \\
\hline 251 & $\mathrm{~A} \rightarrow$ & A & A & A & $\mathrm{P}$ & $\mathrm{P}$ & A (non polar) $\rightarrow$ P (non polar) \\
\hline$\Sigma$ & & $7(9)$ & $3(4)$ & $11(14)$ & $4(5)$ & $4(7)$ & \\
\hline
\end{tabular}


five isolates showed several conserved regions, such as GGGX type, GXSXG (pentapeptide), oxyanion and catalytic triad i.e. serine, aspartate and histidine (Figure 3). The presence of these conserved regions suggesting that the isolates were assigned as a member of family IV

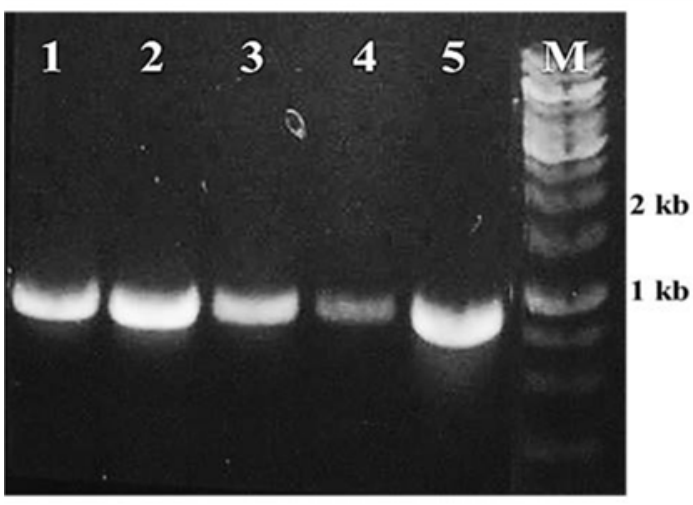

Fig. 1. The results of PCR amplifications of lipase genes. Assigned lane number is as follow 1=lipab4, 2=lipab8, 3= lipab15, 4= lipab18, 5=lipag18 and M=DNA marker
(HSL=Hormone-Sensitive Lipase). Previous study reported that there were a number of bacterial proteins similar to mammalian HSL ${ }^{37}$. Moreover, family members of HSL are very wide, including lipases, esterases and carboxylesterases ${ }^{2}$. Determination of HSL sub family of the lipases

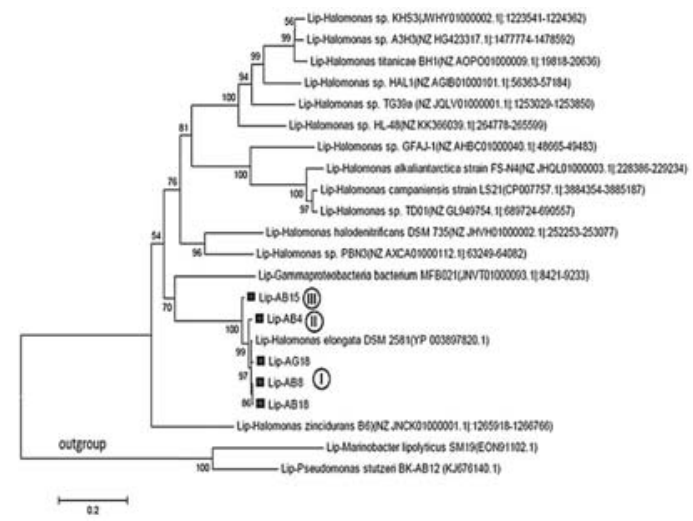

Fig. 2. Phylogenetic profile generated based on lipase sequences of the five isolates

No.

1 ref|WP 013332507.

$2 \mathrm{gb} \mid$ AID 6 6447.1 $1 \mathrm{i}$

$3 \mathrm{gb} \mid$ AID66449.1 $1 i$

$4 \mathrm{gb}|\operatorname{AID} 66450.1| \mathrm{li}$

$5 \mathrm{gb}$ AID66446.1 $\mathrm{li}$

$6 \mathrm{gb} \mid$ AID66448.1 $\mid \mathrm{li}$

7 ref|WP_043487540.

7 ref WP $^{-} 035474917$.

8 ref WP 008960037 .

9 ref|WP_009721885.

.

.

·

97 ref $\mid$ WP $^{-} 033068167$.

98 ref WP_046031202.

99 ref $\mid \mathrm{WP}^{-} 042627437$.

$100 \mathrm{~b} \mid \mathrm{ABD} 5 \overline{3} 304.1$ Alp
GGGX GXSXG
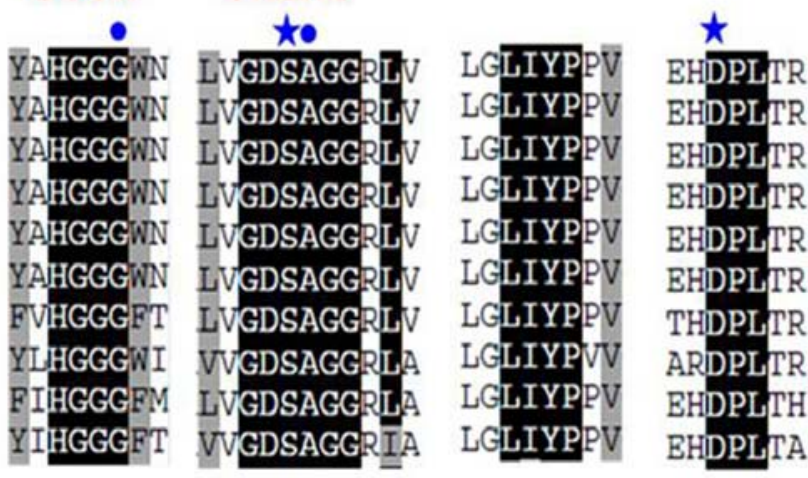

$\stackrel{\star}{\star}$

GMLHGA

GMLHGA

GMLHGA

GMLHGA

GMLHGA

GMVHGA

EMVHSA

QMVHGA

NMVHAA.

Fig. 3. Conserved region of lipase covers GGGX, GXSXG (pentapeptide), oxyanion and catalytic triad in 100 lipase sequences exhibited closer relation to lipase from the five isolates. A description of the figure above is as

follows: oxyanion (๑), catalytic triad ( $\star$ ): serine, aspartate and histidine. Lipase sequences is as follows: liphelo (1), five isolates (2-6) and other lipases closely related with five isolates (7-100) 
were performed based on similarities profiles of The results showed that there are few different conserved regions compared to the lipolytic, lipases, esterases/lipases, esterases and carboxylesterases on the of HSL family members.

regions among the isolates compared to that other lipases, as highlighed by numbers 1-15 (Figure 4). The five lipases are most likely similar to lipolytic

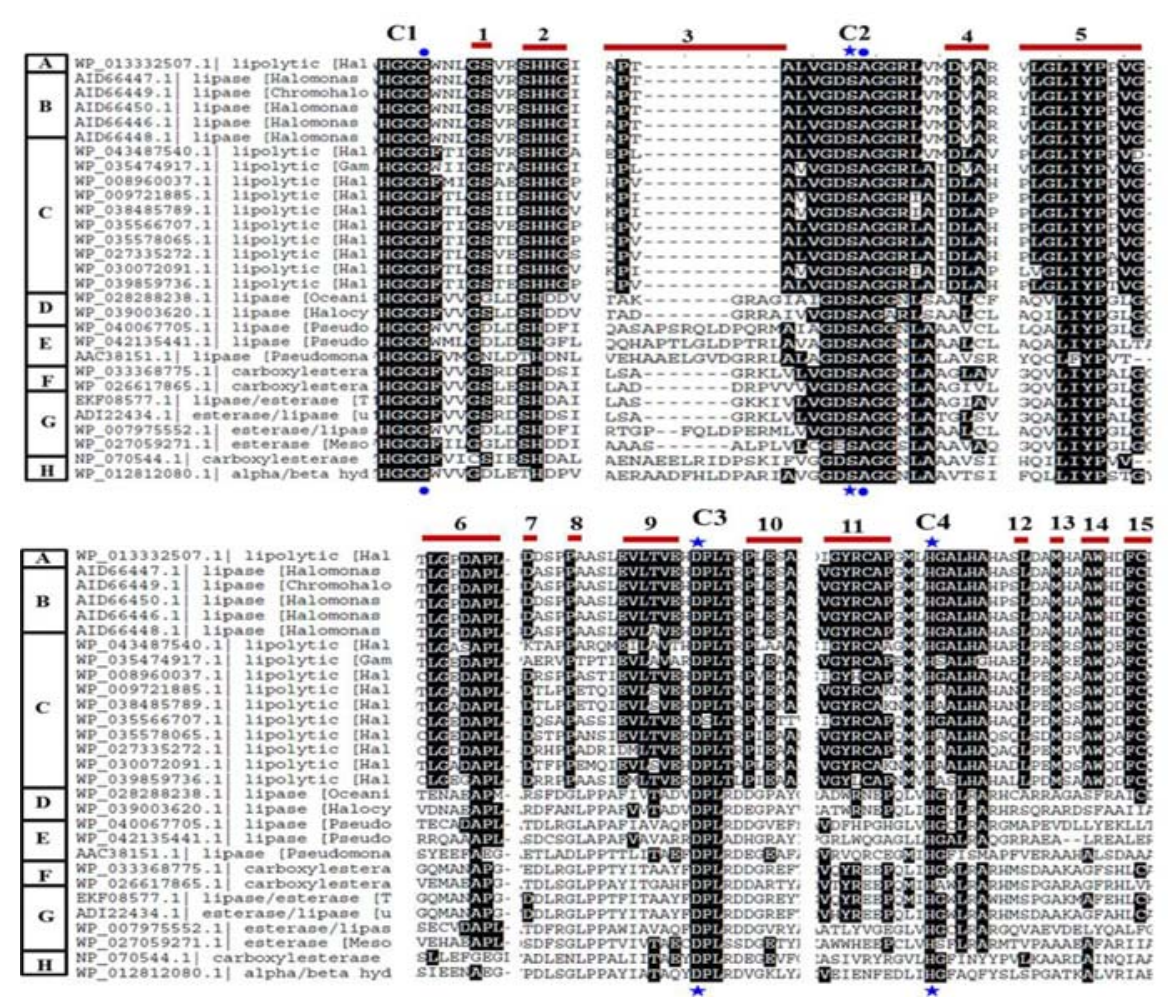

Fig. 4. Differences of conserved region among sequences of lipolytic, lipase, esterase/lipase, carboxylesterase that have close relations with lipase from the five isolates. Description of the above figure is as follows: C1-C4 is conserved regions that owned by each member of family IV lipase (HSL), includes: (C1). GGGX type, (C2). GXSXG (pentapeptide), Oxyanion (•), catalytic triad ( $\star$ ): serine, aspartate (C3) and histidine (C4). Thick lines on the top are regions that showed significant differences between the types of lipase. The sequence number (1-15) is a sequential appearance of such differences. Lipase sequences are as follows: (A). Reference lipase, (B). Lipase of five isolates, (C). Lipolytic of Halomonas, (D). Lipase of halophiles, (E). Lipase of Pseudomonas, (F). Carboxylesterase, (G). Esterase/lipase, (H). Carboxylesterase of thermophile and A/B hydrolase of archaea

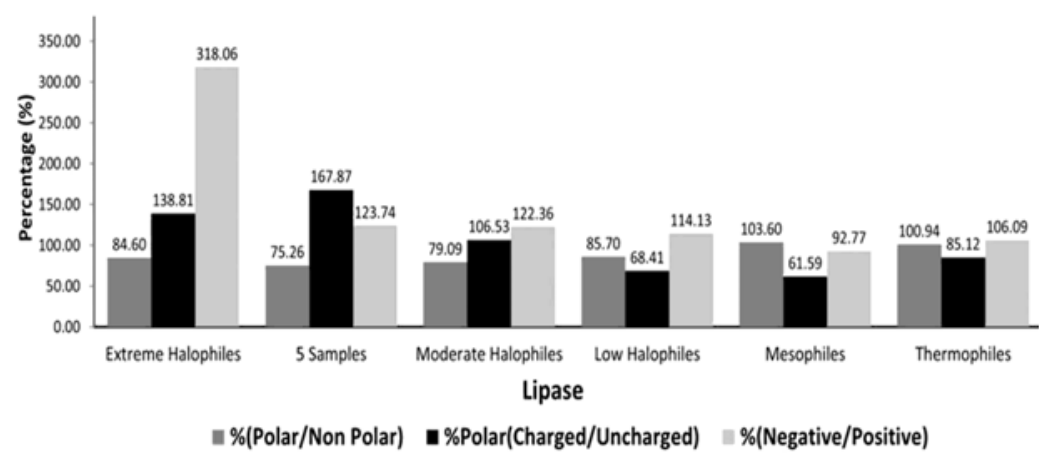

Fig. 5. Amino acid differences among lipase sequences of the five isolates and the other related microorganisms 
of Halomonas, thereby including in moderate halophilic group of enzyme

Detail analysis by comparing the composition of amino acid residues showed that the amino acid composition of the lipases are more predominantly by negatively charged residues compared to that of the mesophilic and thermophilic (Figure 5). However, the composition of negatively charged residues of the five lipases are closer those of moderate halophilic than extreme halophilic. The negatively charged residues of extreme halophilic lipases are usually used to stabilize the protein structures against high salt concentrations $^{38}$.

Further analysis by comparing the amino acid sequences of the five lipases with Halomonas

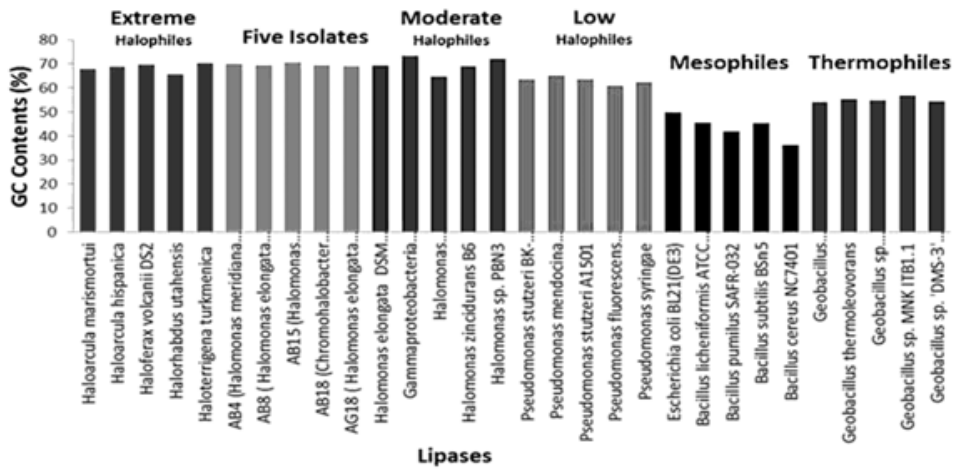

Fig. 6. Percentage of GC content of lipase genes among the five isolates and the other related microorganism

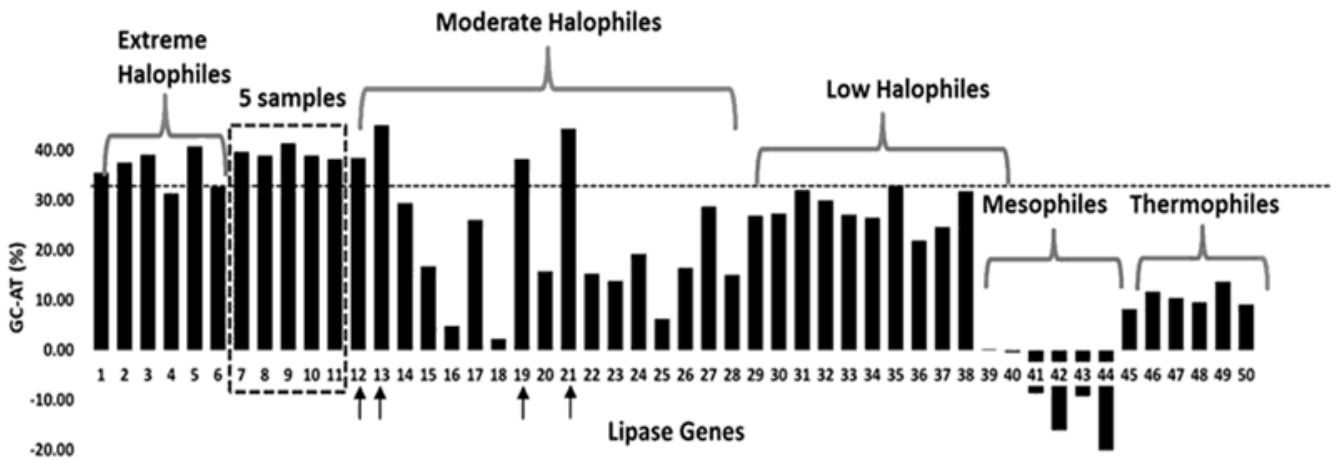

Fig. 7. GC-AT content of lipase between the five isolates and the other related microorganism. Identity of each numbered microorganism is as follow: (1) Haloarcula marismortui ATCC 43049, (2) Haloarcula hispanica ATCC 33960, (3) Haloferax volcanii DS2, (4) Halorhabdus utahensis DSM 12940, (5) Haloterrigena turkmenica DSM 5511, (6) Natronomonas pharaonis DSM 2160; (7) AB4, (8) AB8, (9) AB15, (10) AB18, (11) AG18, (12) Halomonas elongata DSM 2581, (13). Gammaproteobacteria bacterium MFB021, (14). Halomonas halodenitrificans DSM 735, (15). Halomonas sp. TG39a, (16). Halomonas campaniensis strain LS21, (17). Halomonas sp. HL-48, (18). Halomonas alkaliantarctica strain FS-N4, (19). Halomonas zincidurans B6 (20). Halomonas titanicae BH1 (21). Halomonas sp. PBN3 (22). Halomonas sp. KHS3 (23). Halomonas sp. A3H3 (24). Halomonas sp. HAL1 (25). Halomonas sp. TD01 (26). Halomonas sp. GFAJ-1 (27). Chromohalobacter salexigens DSM 3043 (28). Marinobacter lipolyticus SM19 (29). Pseudomonas stutzeri BKAB12 (30). Pseudomonas alcaliphila BK-AG13 (31). Pseudomonas mendocina ymp (32). Pseudomonas mendocina NK-01 (33). Pseudomonas stutzeri A1501 (34). Pseudomonas stutzeri ATCC 17588 (35). Pseudomonas putida NBRC (36). Pseudomonas fluorescens A506 (37). Pseudomonas syringae (38). Pseudomonas aeruginosa (39). Escherichia coli KO11FL (40). Escherichia coli BL21(DE3) (41). Bacillus licheniformis ATCC 14580 (42). Bacillus pumilus SAFR-032 (43). Bacillus subtilis BSn5 (44). Bacillus cereus strain tsu1 (45). Geobacillus stearothermophilus strain ARM1 (46). Geobacillus thermocatenulatus (47). Geobacillus thermoleovorans (48). Geobacillus sp. ‘Papandayan’ ITB2.1 (49). Geobacillus sp. MNK ITB1.1 (50). Geobacillus sp. ‘Domas’ ITB3.1 


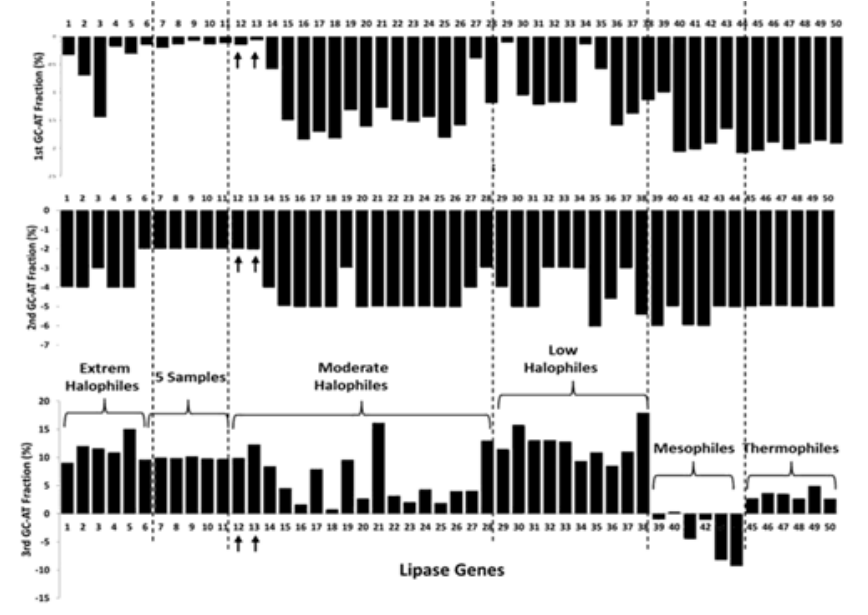

Fig. 8. The difference of bases GC-AT content fractions of "usage codon" of the lipase genes between the five isolates with the other related microorganism. Two moderates halophilics have similar GC-AT content of $1^{\text {st }}, 2^{\text {nd }}$ and $3^{\text {rd }}$ usage codon pattern compared to five lipase genes ie. (12). Halomonas elongata DSM 2581, (13). Gammaproteo bacteria bacterium MFB021 (arrows sign in figure). Identity of each numbered microorganism is similar at figure 6

elongata DSM 2581 showed several differences at some positions. The differences were occurred at residue 98 in lipab15 and lipag18, at residue 168 in lipab4 and lipab15, at residue 188 in lipab4, at residue 191 and 197 in lipab15 and at residue 199 in lipab4, lipab8, lipab15 and lipab18 (Table 2). However, all of the differences were not found within the conserved regions, such as the catalytic site, pentapeptide or oxyanion regions.

\section{Content of GC, GC-AT And GC-AT Codon Usage of Lipase Genes}

Further analysis was conducted by comparing GC content or GC content on the codon usage in order to a unique characteristic of halophilic. The high GC content of the genome is a common feature of extreme halophilic ${ }^{39,40,41}$. GC content on the third (wobble) position of codon usage is corresponding to over-representation of the translated amino acid, which is for halophilic proteins correspond to the abundance of acidic residues ${ }^{39}$. Therefore, overrepresentation of acidic residues is an adaptation to high salinity that is apparent in the codon usage of the organism.

Based on the above studies, we were further investigated the halophilic properties by comparing content of GC, GC-AT and GC-AT of codon usage of the lipase genes with other microorganism. GC content analysis showed that the five lipase genes are closer to all groups of halophilic (Figure 6). The similarities of GC content of the genes with those of halophilic are unique characteristics of the isolates. This was correlating to their niches at high salinity level. Meanwhile, the result of GC-AT content analysis of the genes further exhibited a unique pattern as follows, 5 samples $=$ average of halophiles $>$ thermophiles $>$ mesophiles (Figure 7). We further analyzed GC-AT content of codon usage on the first, second and third positions. The result showed the GC-AT content for the third base displayed similar unique pattern to the last two analysis (Figure 8). Therefore the GC-AT content for the third base of codon usage of the genes may be used as differentiator of halophilic lipase from various groups of microorganism. In general, the third base position of the gene is determinant base of codon preferences for each microorganism ${ }^{42}$. All of the analysis above suggest that the lipase genes of five isolates are closer to moderate halophilic, which is Halomonas elongata DSM 2581.

\section{CONCLUSSION}

Lipase genes have been successfully isolated from five moderately halophilic bacteria of Bledug Kuwu (BK) isolates and cloned into $E$. coli Top 10. The lipase of five isolates is classified as a member of family IV lipase (HSL=Hormone- 
Sensitive lipase) as indicated by the existence of Gly-X-Ser-X-Gly pattern in their conserved regions. The conserved region of the five lipases has high similarities to that of lipolytic Halomonas and formed a distinct cluster with other types of HSL lipase, such as esterase/lipase and carboxylesterase. Amino acids composition of the five lipases are closer to the moderate halophilic group, in which they have more negatively charged residues than the mesophilic and thermophilic ones. Homology and phylogenetic profile of the five lipase genes distributed them into three groups i.e. Group I (lipab8, lipab18 and lipag18) that closely related to lipolytic gene of Halomonas elongata DSM 2581, while groups II (lipab4) and III (lipab15) created new branches in the phylogenetic tree. Narrowing analysis to GC and GC-AT content has successfully revealed the unique pattern of the five-lipase genes compared to other microorganism, such as thermophiles and mesophiles. More specific analysis on GC-AT content of codon usage exhibited consistent result with both morphology and phylogenetic analyses above.

\section{ACKNOWLEDGEMENTS}

This work is funded by university priority research grant with the contract number: $310 \mathrm{u} /$ 11.C01/PL/2015 awarded to R.H.

\section{REFERENCES}

1. Gill J, Parish JH. Minireview: Lipasesenzymes at an interface. Biochem Educ. 1997; 25(1): 2-5.

2. Arpigny JL, Jaeger K-E. Bacterial lipolytic enzymes: classification and properties. Biochem J. 1999; 343(1): 177-183.

3. Hasan F, Shah AA, Hameed A. Industrial applications of microbial lipases. Enzyme Microb Technol. 2006; 39(2): 235-251.

4. Ghasemi Y, Rasoul-Amini S, Kazemi a., Zarrini G, Morowvat MH, Kargar M. Isolation and characterization of some moderately halophilic bacteria with lipase activity. Microbiology. 2011; 80(4): 483-487.

5. Widhiastuty MP, Febriani, Moeis MR, Akhmaloka, Madayanti F. Cloning, homological analysis and expression of Lipase gene from hot spring isolate. Int J Integr Biol. 2011; 11(1): 813.
6. Febriani, Ihsanawat, Hertadi R, Madayanti F, Akhmaloka. Thermostable alkaline lipase isolated from thermus aquaticus. Int $J$ Integr Biol. 2013; 14(2): 104-112.

7. Aditiawati P, Yohandini H, Madayanti F, Akhmaloka. Microbial diversity of acidic hot spring (kawah hujan B) in geothermal field of kamojang area, west java-indonesia. Open Microbiol J. 2009; 3: 58-66.

8. Akhmaloka A, Suharto a., Nurbaiti S, N. Tika I, M. Warganegara F. Ribotyping Identification of Thermophilic Bacterium from Papandayan Crater. ITB J Eng Sci. 2006; 38(1): 1-10.

9. Nurhasanah, Nurbaiti S, Warganegara FM, Akhmaloka. Diversity of gene encoding thermostable Lipase from compost based on metagenome analysis Isolation of total DNA community from compost. Int J Integr Biol. 2015;16(1):7-12.

10. Brilliantoro R, Zidny R, Widhiastuty MP, Akhmaloka. Hydrolytic and Transesterification Activities of Thermostable Lipase ITB1.1. Biosci Biotechnol Res Asia. 2015; 12(April): 1-6.

11. Gupta GN, Srivastava S, Khare SK, Prakash V. Extremophiles: An Overview of Microorganism from Extreme Environment. Int J Agric Environ Biotechnol. 2014; 7(2): 371-379.

12. Sánchez-Porro C, Martín S, Mellado E, Ventosa a. Diversity of moderately halophilic bacteria producing extracellular hydrolytic enzymes. $J$ Appl Microbiol. 2003; 94(2): 295-300.

13. Kumar S, Karan R, Kapoor S, Singh SP, Khare SK. Screening and isolation of halophilic bacteria producing industrially important enzymes. Brazilian J Microbiol. 2012; 43(4): 1595-1603.

14. Litchfield CD. Survival strategies for microorganisms in hypersaline environments and their relevance to life on early Mars. Meteorit Planet Sci. 1998; 33(4): 813-819.

15. Ma Y, Galinski E a., Grant WD, Oren A, Ventosa A. Halophiles 2010: Life in saline environments. Appl Environ Microbiol. 2010; 76(21): 69716981.

16. Amoozegar MA, Salehghamari E, Khajeh K, Kabiri M, Naddaf S. Production of an extracellular thermohalophilic lipase from a moderately halophilic bacterium, Salinivibrio sp. strain SA-2. J Basic Microbiol. 2008; 48(3): 160167.

17. Boutaiba S, Bhatnagar T, Hacene H, Mitchell D a., Baratti JC. Preliminary characterisation of a lipolytic activity from an extremely halophilic archaeon, Natronococcus sp. J Mol Catal B Enzym. 2006; 41(1-2): 21-26.

18. Ozcan B, Ozyilmaz G, Cokmus C, Caliskan M. Characterization of extracellular esterase and 
lipase activities from five halophilic archaeal strains. J Ind Microbiol Biotechnol. 2009; 36(1): 105-110.

19. Rohban R, Amoozegar MA, Ventosa a. Screening and isolation of halophilic bacteria producing extracellular hydrolyses from Howz Soltan Lake, Iran. J Ind Microbiol Biotechnol. 2009; 36(3): 333-340.

20. Li X, Yu H-Y. Characterization of a novel extracellular lipase from a halophilic isolate, Chromohalobacter sp. LY7-8. African J Microbiol Res. 2012; 6(14): 3516-3522.

21. Pérez D, Martín S, Fernández-Lorente G, et al. A novel halophilic lipase, LipBL, showing high efficiency in the production of eicosapentaenoic acid (EPA). PLoS One. 2011; 6(8): 1-11.

22. Tiquia SM, Davis D, Hadid H, et al. Halophilic and halotolerant bacteria from river waters and shallow groundwater along the Rouge River of southeastern Michigan. Environ Technol. 2007; 28(3): 297-307.

23. Sellek G a., Chaudhuri JB. Biocatalysis in organic media using enzymes from extremophiles. Enzyme Microb Technol. 1999; 25(6): 471-482.

24. Doukyu N, Ogino H. Organic solvent-tolerant enzymes. Biochem Eng J. 2010; 48(3): 270-282.

25. Asy'ari M, Parwata IP, Aditiawati P, Akhmaloka, Hertadi R. Isolation and Identification of Halostable Lipase Producing Bacteria from the Bledug Kuwu Mud Crater Located at Purwodadi-Grobogan, Central Java , Indonesia. J Pure Appl Microbiol. 2014; 8(5): 3387-3396.

26. Parwata IP, Asyari M, Hertadi R. Organic Solvent-Stable Lipase from Moderate Halophilic Bacteria Pseudomonas stutzeri Isolated from the Mud Crater of Bleduk Kuwu, Central Java, Indonesia. J Pure Appl Microbiol. 2014; 8(1): 31-40.

27. Sezonov G, Joseleau-Petit D, D’Ari R. Escherichia coli physiology in Luria-Bertani broth. J Bacteriol. 2007; 189(23): 8746-8749.

28. Stach JE., Bathe S, Clapp JP, Burns RG. PCRSSCP comparison of $16 \mathrm{~S}$ rDNA sequence diversity in soil DNA obtained using different isolation and purification methods. FEMS Microbiol Ecol. 2001; 36(2-3): 139-151.

29. Mullis K, Faloona F, Scharf S, Saiki R, Horn G, Erlich H. Specific Enzymatic Amplification of DNA In Vitro: The Polymerase Chain Reaction. Cold Spring Harb Symp Quant Biol. 1986; 51: 263-273.

30. Cohen SN, Chang AC, Hsu L. Nonchromosomal antibiotic resistance in bacteria: genetic transformation of Escherichia coli by R-factor
DNA. Proc Natl Acad Sci U S A. 1972; 69(8): 2110-2114.

31. Inoue H, Nojima H, Okayama H. High efficiency transformation of Escherichia coli with plasmids. Gene. 1990; 96(1): 23-28.

32. Bimboim HC, Doly J. A rapid alkaline extraction procedure for screening recombinant plasmid DNA. Nucleic Acids Res. 1979; 7(6): 1513-1523.

33. Sanger F, Nicklen S, Coulson a R. DNA sequencing with chain-terminating inhibitors. Proc Natl Acad Sci U S A. 1977; 74(12): 54635467.

34. Schwibbert K, Marin-Sanguino A, Bagyan I, et al. A blueprint of ectoine metabolism from the genome of the industrial producer Halomonas elongata DSM 2581 T. Environ Microbiol. 2011; 13(8): 1973-1994.

35. Joseph TC, Baby A, Reghunathan D, Varghese AM, Murugadas V, Lalitha K V. Draft Genome Sequence of the Halophilic and Highly Halotolerant Gammaproteobacteria Strain MFB021. Genome Announc. 2014; 2(6): e01156-14 - e01156-14.

36. Sakurai T, Nakashima S, Kataoka K, Seo D, Sakurai N. Diverse NO reduction by Halomonas halodenitrificans nitric oxide reductase. Biochem Biophys Res Commun. 2005;333(2):483-487.

37. Hemilä H, Koivula TT, Palva I. Hormonesensitive lipase is closely related to several bacterial proteins, and distantly related to acetylcholinesterase and lipoprotein lipase: identification of a superfamily of esterases and lipases. Biochim Biophys Acta. 1994; 1210(2): 249-253.

38. Lanyi JK. Salt-dependent properties of proteins from extremely halophilic bacteria. Bacteriol Rev. 1974; 38(3): 272-290.

39. Kennedy SP, Ng WV, Salzberg SL, Hood L, DasSarma S. Understanding the adaptation of Halobacterium species NRC-1 to its extreme environment through computational analysis of its genome sequence. Genome Res. 2001; 11(10): 1641-1650.

40. Paul S, Bag SK, Das S, Harvill ET, Dutta C. Molecular signature of hypersaline adaptation: insights from genome and proteome composition of halophilic prokaryotes. Genome Biol. 2008; 9(4): R70.1-R70.19.

41. Soppa J. From genomes to function: Haloarchaea as model organisms. Microbiology. 2006; 152(3): 585-590.

42. Andersson SG, Kurland CG. Codon preferences in free-living microorganisms. Microbiol Rev. 1990; 54(2): 198-210. 